\title{
Effectiveness Implementation of Management Information System A Case Study in Badung, Indonesia
}

\author{
I Made Wimas Candranegara \\ Department Public Administration, \\ Warmadewa University, \\ Denpasar, Indonesia \\ wimascandranegara3491@gmail.com
}

\author{
I Dewa Gede Putra Sedana \\ Department Public Administration, \\ Warmadewa University, \\ Denpasar, Indonesia \\ wemust91@yahoo.com
}

\begin{abstract}
In the research of the Implementation effectiveness policy of management information systems in the area in local revenue department (Dispenda) Badung regency, is focused on variables implementation, namely the implementation of the communication factor, resources, attitudes and the targets realization of local revenue department. The problem of this research is how effective the implementation of management information systems in the area of revenue department Badung regency. To prove that what is described in this research is actual data, and then the research is used to obtain the data needed for solving the problem. This data accumulation used observation, questionnaires, interviews and documentation for further obtain data, and the data were analyzed with quantitative analysis and qualitative analysis. The data obtained from local revenue department that have effective implementation policy SIMAPATDA. It can be seen from the score of the indicators of communication, resources and attitudes that exist in the high category and is reinforced by the results of an interview with the secretary of the local revenue department, Badung regency and revenue targets also realization of regional fiscal year 2009 to 2013 and based on the average of the included in the high category.
\end{abstract}

Keywords: effective implementation, public policy; management information system

\section{INTRODUCTION}

Public service as one of the main functions of the government is as an effort to fulfill the needs of the community for the procurement of services that the community needs. Public service which is widely known with the bureaucratic nature and many complaints from the public of its customers, among others, due to still not paying attention to the interests of the community users. To further encourage the commitment of the government apparatus towards the improvement of the quality of service, so has been issued also Presidential Instruction No. 1 of 1995 on the Improvement and Improvement of the Quality of Government Apparatus Services to the Community. In the latest development has been issued also Decree No. 63 / KEP / M.PAN / 7/2003 on General Guidelines for the Implementation of Public Services. In order to realize Local Tax System based on Information Technology in Badung Regency Government

Corresponding authors: I Made Wimas Candranegara especially at Local Revenue Service / Pasedahan Agung built an Information Technology Technology (IT) System of Local Taxation which is called Regional Revenue Management Information System (SIMAPATDA). In the research of Effectiveness of Policy Implementation of Revenue Management Information System at District Revenue Service (Dispenda) of Badung Regency, limited and focused implementation variables are on communication factor, resources, attitudes and target realization of regional income. In connection with the things that have been described above, the title of research on the Effectiveness of Policy Implementation of Regional Revenue Management Information System in the District Revenue Office of Badung Regency ". Thus the problems in this study can be formulated as follows: "How Effectiveness of the implementation of Regional Revenue Management Information System Policy in the Office of Revenue District Badung".

Effectiveness is a measure that states how far the target (quantity, quality and time) has been achieved ${ }^{[1]}$. if the realization of the program 1 percent - 50 percent of the target including low effectiveness, whereas if the realization between 51 percent - 100 percent of the target including high effectiveness. From these terms it can be said that effectiveness is a profile or form of effect that shows a measure that states how far the target (quantity, quality and time) of effectiveness at each target it has. If the realization of $1 \%-50 \%$ of the target including low effectiveness, whereas if the realization between $51 \%-100 \%$ of the target. ${ }^{[2]}$

Policy implementation is seen in the broadest sense as a legal administration tool where various actors, organizations, procedures, and techniques work together to implement policies to achieve impacts or objectives desired. ${ }^{[3]}$ Implementation on the other hand is a complex phenomenon that may be understood as a process, output (output) and as a result.

Management information system is a computerbased system that provides information for multiple users with similar needs ${ }^{[4]}$. From some of the above understanding put forward SIM is a data processing system in an organization that serves to handle the process of collecting, processing, and storing data 
that provides accurate and timely information for users of information as a support decision-making (managerial process). Regional revenues are all receipts of money through regional public treasury accounts that add equity of current funds which are the right of local government within 1 (one) budget year which is not required to be repaid by the region [5]. where the sources of regional income are derived from PAD, Balancing Fund and Other valid receipts. The operational definition used in this research is communication, attitude, and resources.

\section{RESEARCH METHOD}

The research method used in this study used descriptive research where the analysis used in this study using quantitative and qualitative data analysis. The population in Badung District Income Office amounted to 207 staff / employees with the determination of samples by taking $25 \%$ of the population where the sample used amounted to 52 people where the technique of determining the sample used is Proportional Random Sampling. The techniques of data collection using observation techniques, questionnaires, interviews and documentation. In data analysis techniques use the stages of scoring and determine the boundaries of interpretation answers.

\section{RESULT AND DISCUSSION}

The results of research and discussion in this study obtained that the overall response results based on parameters / communication indicators obtained score 1617 including high category. Meanwhile, based on interviews with Secretary of Revenue Office of Badung Regency. According to an interview with the Regional Secretary of the AAA Gede Agung Arimayun Revenue Service, STP., M. Par (dated January 12, 2015) related to superior communication with superiors, subordinate supervisors and communications between officers of officers of SIMAPATDA officers while interviewed, in Badung District Revenue Office, he said that the communications of superiors with subordinates, subordinate boss and communication between employees running well and the staff of the Regional Revenue Office of Badung Regency already know the validity of SIMAPATDA. Based on parameter / indicator of resources obtained score 1298 including high category. And can be supported based on the results of interviews with Sekretarsi Dinas Pendapatan Daerah Kabupaten Badung. According to interviews with Secretary of Badung District Revenue Office AA Gede Agung Arimayun, STP., M. Par (dated January 12, 2015) regarding resources to support the effectiveness of the implementation of the SIMAPATDA policy said that in carrying out activities / efforts to support the effectiveness of Implementation of SIMAPATDA in Dinas Pendapatan Kabupaten Badung is quite adequate. Has provided complete and adequate tools such as transportation facilities, computerization and the ability of employees in performing their duties in accordance with their fields. Based on parameter / attitude indicator obtained 1079 value including high category. And can be supported based on the results of interviews with the Secretary of Revenue Office of Badung regency. According to interviews with the Secretary of Badung District Revenue Office AA Gede Agung Arimayun, STP., M. Par (dated January $12,2015)$ regarding employee attitudes to support the effectiveness of the implementation of the policy SIMAPATDA said that the attitude of employees in the Office of Revenue Badung very supportive with SIMAPATDA policy so expected accuracy of data can be guaranteed, employees can be more compliant / discipline in work and improvement of employee skills. So it can be said that the attitude of employees to support the effectiveness of SIMAPATDA policy implementation in Badung Regency Revenue Service is good, it can be seen from the score and the average included in the high category and supported by interviews delivered. that the attitude of employees in Badung District Revenue Service is very supportive with SIMAPATDA policy, expected accuracy of data can be guaranteed, employees can be more compliant / discipline in work and employee skill improvement. Overall effectiveness of SIMAPATDA policy implementation in Badung Revenue Service is measured through communication, resources, and attitude with 18 parameters above, all of them are high. Total score 3994 is 3433 - 4680 high. In the analysis of the central tendency, the mean score is on score 77.23 which is included in the pre-eminent category found in the interval classes $76-81$. The mode obtaining a score of 75.1 indicates that the largest frequency concentration is found in the interval class $70-75$. So it can be said that most respondents chose the answer very well. Median scored 76.4 which showed very good category. This shows the midpoint values that divide all the numbers (data) at the $76-81$ class intervals.

In the effectiveness analysis seen from the achievement of targets and realization shows that in fiscal year 2009 the target is set at Rp.1.309.318.366.307 while the realization of Rp.1.350.659.167.377 or $103.16 \%$ exceeds the target set. Target fiscal year 2010 is set at Rp.1.217.867.305,390 while the realization is $\mathrm{Rp}$. $1,425,603,710,748$ or $117.06 \%$ exceeds the specified target.

\section{CONCLUSION}

The conclusion that can be drawn in this research is Communication at Regional Revenue Office of Badung regency has been running well. This can be seen through the scores and averages included in the high category, and through the results of interviews on communications indicator said that communication between superiors with subordinates, subordinates with superiors, and communication between employees is running well and the employees in the Office of Revenue Regencies of Badung Regency already know the validity of SIMAPATDA. The resources to support the effectiveness of SIMAPATDA policy 
implementation in Badung District Revenue Service have been good, this can be seen through the score and the average that included in high category and supported by interview result where it is said that there are available complete and sufficient tools such as means of transportation, computerization and the ability of employees in carrying out their duties are in accordance with their fields. Attitudes of employees to support the effectiveness of SIMAPATDA policy implementation in Badung District Revenue Service has been good, this can be seen through the score and the average that included in the high category and supported by the results of interviews that the attitude of employees in the Office of Revenue District Badung very supportive with the policy of SIMAPATDA hence expected accuracy of data can be guaranteed, employee can more obedient / discipline in work and skill improvement of employee. Calculation of the central tendency with the mode score where the largest frequency is at a score of 75.1 which is included in the category is very good. Median which is the midpoint obtained 76.4 score found in interval classes $76-81$. For the average obtained a score of 77.23 which is included in the category very well. From the calculation of the central tendency of the results of the questionnaire scores of respondents, it can be said that the effectiveness of SIMAPATDA Policy Implementation has been very good. Increased Target and Realization of Regional Income Fiscal Year 2009 to 2013.
Based on the results of the analysis that has been done, it can be submitted suggestions as follows: The effectiveness of SIMAPATDA policy implementation in Badung District Revenue Service has been very good, therefore must be maintained and enhanced by giving training to employees to improve employee performance. The need for a growing regulation in order to improve the effectiveness of SIMAPATDA policy implementation in Badung District Revenue Service Office.

\section{REFERENCES}

[1] Hidayat, "Theory of Effectiveness In Employee Performance". Yogyakarta: Gajah Mada University Press, 1986.

[2] A. W. Subagyo, The Effectiveness of Poverty Reduction Program in Rural Empowerment. Yogyakarta: UGM, 2000.

[3] J.P. Lester and J. Stewart, "Public Policy: An Evolution ary Approach, Belmont: Wads worth", 2000.

[4] McLeod, Raymond, Shell, George P. 2007, Management Information System. Edition 10. New Jersey: Prentice Hall

[5] UU no. 33 Year 2004 